症例

von Recklinghausen 病患者に発生した非機能性褐色細胞腫と 後腹膜悪性神経鞘腫の 1 切除例

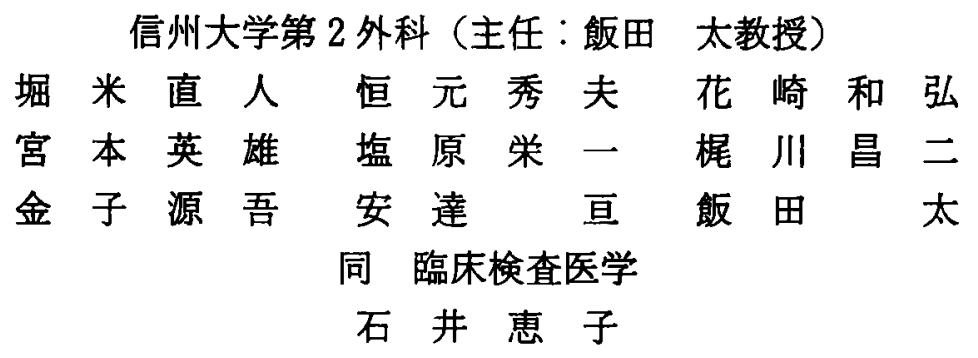

von Recklinghausen 病患者に発生した, 非機能性褐色細胞腫と後腹膜悪性神経䩪腫の 1 切除例を報告する。症例は48歳女性で，祖母，母，妹に von Recklinghausen 病の発 症がみられている。発熱, 腹部尰瘤を主訴に来院し, 全身に café au lait spots と多数 の神経線維腫が認められた。腹部 US, CT 検査, 血管造影検查の結果, 右副腎原発の直 径 $13 \mathrm{~cm}$ の腫瘍と, 大動脈腹側の後腹膜に舀卵大の腫瘍が存在していることが判明した。 副腎腫瘍は感染により膿場化し，内分泌学的検索で非活性腫湟であった。両腫場の切除 術を施行した。右副腎腫場は $13 \times 15 \times 13 \mathrm{~cm}$ ，重さ $694 \mathrm{~g}$ ，中央は壊死に陥り赤褐色膿様液 を入れていた。 大動脈腹側の後腹膜腫㕫は $5 \times 5 \times 3 \mathrm{~cm}$, 黄色充串性であった。病理組織学 的検索により前者は悪性褐色細胞腫, 後者は悪性神経䩗腫であることが判明した。

妻引用語：von Recklinghausen 病, 褐色細胞腫, 後腹膜悪性神経䩗腫

はじめに

von Recklinghausen 病（以下 $\mathrm{R}$ 病と略す）は，特 徵的な皮虙所見を示す常染色体優性遺伝疾患で，種々 の悪性疾患を合併することが知られている(1)2)，とく $k$, 神経肉腫, 脑神経腫場, 悪性神経鞘腫等の神経原 性腫場の合併はよく知られている3゙が，褐色細胞腫や 消化器癌の合併もみられる4 に合併した非機能性悪性褐色細胞腫および悪性神経鞈 腫の 1 例を程験したので報告する。

$$
\text { 症例 }
$$

患者：48歳，女性。

主訴：発熱, 腹部膨満感.

家族歴：祖母，母，妹に $\mathrm{R}$ 病の発症をみる。

既往歴：小児期から $\mathrm{R}$ 病が発生した。 38歳時, 絽隔 連瘍の切除術をらけた。

現病歴：昭和63年 3 月上旬から $38^{\circ} \mathrm{C}$ を越古る発熱が あり近医を受診した。血液検查で白血球增多とトラン スフミナーゼの上昇がみられ, 腹部超音波検査（以下

1990 年 6 月 25 日受付 1991 年 1 月 8 日採用
腹部 US と略す), Computed Tomography (以下 CT と略す）で巨大な肝膿瘍が疑われたため, 精查加療の 目的で当科に入院した。

入院時現症：身長 $150 \mathrm{~cm}$, 体重 $51 \mathrm{~kg}$, 血正108-70 $\mathrm{mmHg}$, 全身に café au lait spots と大豆大までの神 経線維腫が多発していた。眼䀫結膜に貧血なく，眼球 強膜に黄疾はなかった。胸部理学的所見に異常はみら れなかったが, 腹部所見では右悸肋部に 2 横指の腫瘤 を触知した。血液検査では，表 1 のごとく白血球增多，

表 1 血液生化学検查所見

\begin{tabular}{lclc}
\hline $\mathrm{RBC}$ & $458 \times 10^{4} / \mathrm{mm}^{3}$ & $\mathrm{Na}$ & $138 \mathrm{mEq} / \mathrm{l}$ \\
$\mathrm{Hb}$ & $12.8 \mathrm{~g} / \mathrm{dl}$ & $\mathrm{K}$ & $4.1 \mathrm{mEq} / 1$ \\
$\mathrm{Ht}$ & $41.0 \%$ & $\mathrm{Cl}$ & $104 \mathrm{mEq} / 1$ \\
$\mathrm{~W} \mathrm{BC}$ & $11200 / \mathrm{mm}^{3}$ & & \\
T.P & $6.3 \mathrm{~g} / \mathrm{dl}$ & $\mathrm{CRP}$ & $15.6 \mathrm{mEq} / \mathrm{dl}$ \\
$\mathrm{T} . \mathrm{Bil}$ & $0.2 \mathrm{~g} / \mathrm{dl}$ & $\mathrm{AFP}$ & $<5.0 \mathrm{ng} / \mathrm{ml}$ \\
$\mathrm{GOT}$ & $43 \mathrm{IU}$ & $\mathrm{CA} 19-9$ & $24.8 \mathrm{IU} / \mathrm{ml}$ \\
$\mathrm{GPT}$ & $92 \mathrm{IU}$ & $\mathrm{CEA}$ & $0.8 \mathrm{IU} / \mathrm{ml}$ \\
LDH & $119 \mathrm{IU}$ & & \\
ALP & $420 \mathrm{IU}$ & $\mathrm{ESR}$ & $83 \mathrm{~mm} / \mathrm{h}$ \\
$r-\mathrm{GTP}$ & $311 \mathrm{IU}$ & & \\
\hline
\end{tabular}




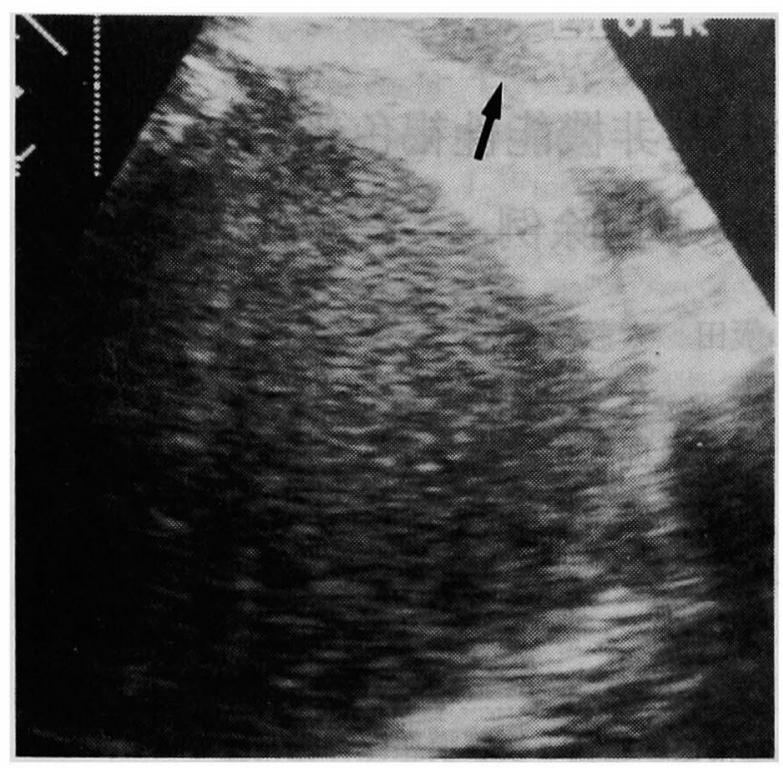

図 1 腹部 US 検査所見: 辺縁は高ェコーで中央は 均一な低ェコーを示す巨大な腫瘤で肝は左前方へ王 排偏位している (矢印).

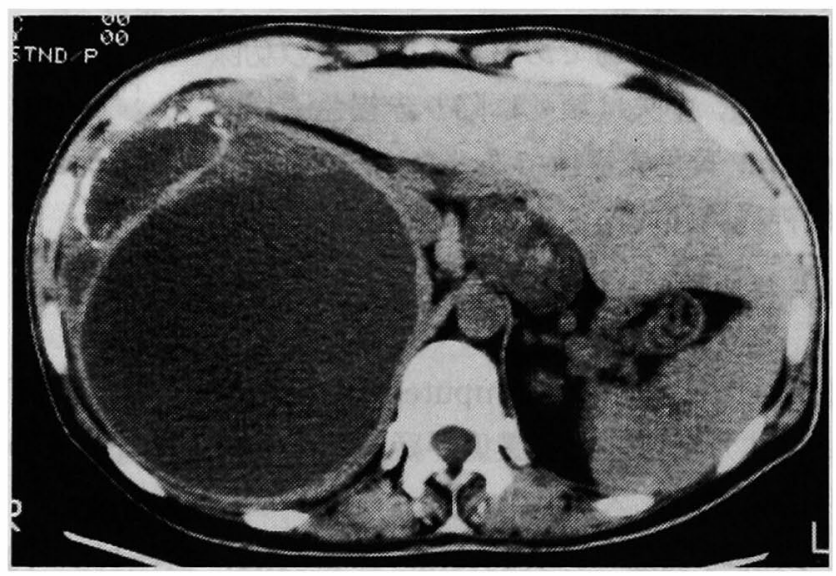

図 2 腹部 CT: 副腎の位置に辺縁が薄い被膜様の高 吸収域を示し, 中央部が均質な低吸収域を示す $13 \times$ $15 \mathrm{~cm}$ の巨大腫瘤と大動脈腹側に充実性腫瘤を認め る.

CRP 強陽性, 赤沈値の六進がみられ, GOT, GPT, $\gamma$-GTP の軽度の増加が認められた。

腹部 US 所見：図 1 のごとく肝を左方，腎を下方へ 強く生排する巨大な腫瘤が認められた。この腫瘤は辺 縁が高ェコ一域で一部には石灰化むみられ，中心部は 均一な低エコーを呈した。

腹部 CT 所見：図 2 のごとく，腫瘤は右副腎に相当 する位置に存在し，球形で大きさ $13 \times 12 \mathrm{~cm}$ であった。 中心部はwater density 示すが，辺縁には薄い被膜 様の実質部分が残存し，巨大な震胞様所見を示した。 この腫瘤は造影 CT で enhanceされなかったが,これ

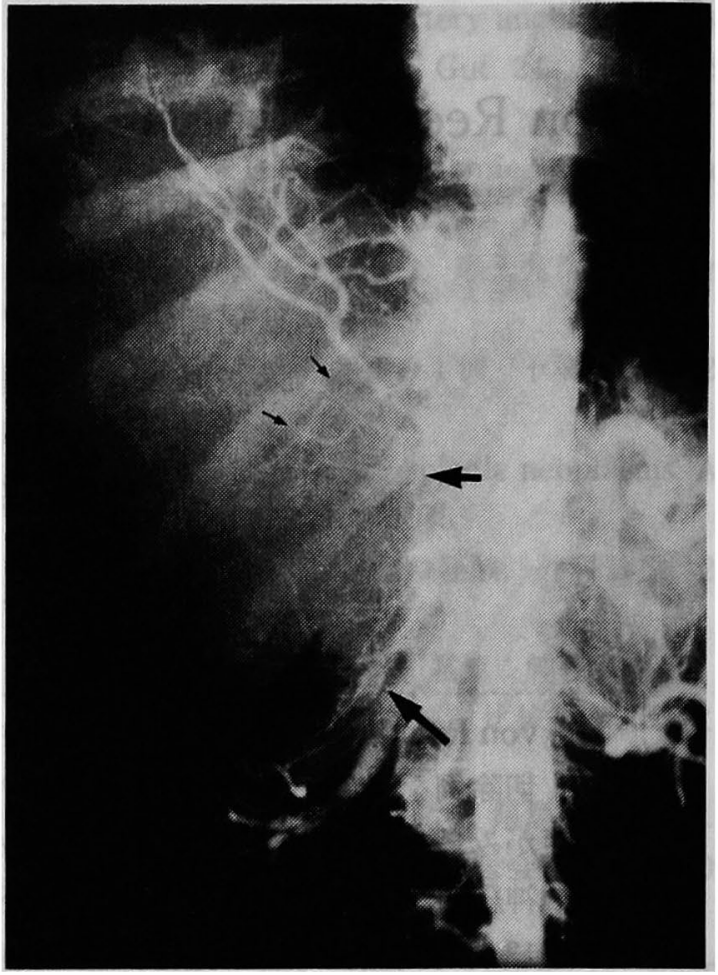

図 3 選択的腹部血管造影：巨大腫瘤は副腎動脈

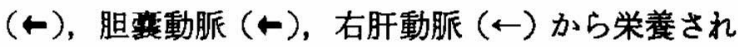
るが，血管増生は乏しい，大動脈腹側の腫癌に一致 して腹腔動脈枝からの腫晹濃染像を認める。

表 2 ホルモン検査所見

\begin{tabular}{llc}
\hline 血中 & コルチゾール & $11.7 \mu \mathrm{g} / \mathrm{dl}$ \\
尿中 VMA & $5.0 \mathrm{mg} / \mathrm{day}$ \\
& HVA & $4.6 \mathrm{mg} / \mathrm{day}$ \\
& 5-HIAA & $3.0 \mathrm{mg} / \mathrm{day}$ \\
アドレナリン & $11.4 \mu \mathrm{g} / \mathrm{dy}$ \\
ノルフドレナリン & $120 \mu \mathrm{g} / \mathrm{dy}$ \\
ドハシン & $800 \mu \mathrm{g} / \mathrm{dy}$ \\
メタネフリン & $0.14 \mathrm{mg} / \mathrm{day}$ \\
ノルメタネフリン & $0.28 \mathrm{mg} / \mathrm{day}$ \\
\hline
\end{tabular}

とは別に腹部大動脈の腹側に enhance される $5 \times 3 \mathrm{~cm}$ の充実珄腫瘤が認められた。

以上よりリンパ節転移を伴った副腎腫瘍と診断し た.ホルモン定量を行ったが，表 2 のごとく，尿中の カテコラミンおよびその代謝産物, 副腎皮質ホルモン に異常はみられず, 内分泌非活性副腎腫瘍と考点られ た。

血管造影所見：褐色細胞腫を考慮し，大動脈造影で 血王の変動のないことを確認した後に選択的動脈造影 を行った。図 3 のごとく右副腎は副腎動脈と胆覇動脈 および右肝動脈から血流をうけているが，腫崵内の血 
管は非常に乏しい，下大静脈は腫漡により左前方へ圧 排偏位しているが，浸潤像はみられなかった，腹部大 動脈腹側の後腹膜腫湯は腹腔動脈の分枝から栄養さ れ，腫瘍血管の増生が著明であり副腎腫湯の転移とは 考えられず，別の腫瘍が疑われた。

入院後，強力な抗生剂投与を行ったが解熱せず，副 腎腫湯の中心壊死，膿湯化が考えられたため，エコー ガイド下穿刺ドレナージを行った。コレステリン結晶 を大量に含む赤褐色膿性液が約 $500 \mathrm{cc}$ 排出された。細 菌培養により腸球菌が検出されたため，感受性薬剤の 投与を続けたが発熱は続き，腫瘍の縮小もみられな かった。炎症所見が残っていたが腫瘤摘出術を行った。

手術所見：図 4 のごとく副腎腫瘍は肝と右腎を王排 するよらに発育し, 被膜は厚く, 周囲々強固に癒着し ていたため，鋭的剥離を行い切除した。また，腹部大 動脈腹側の後腹膜腫瘍は, 鶏卵大で左胃動脈をまき込

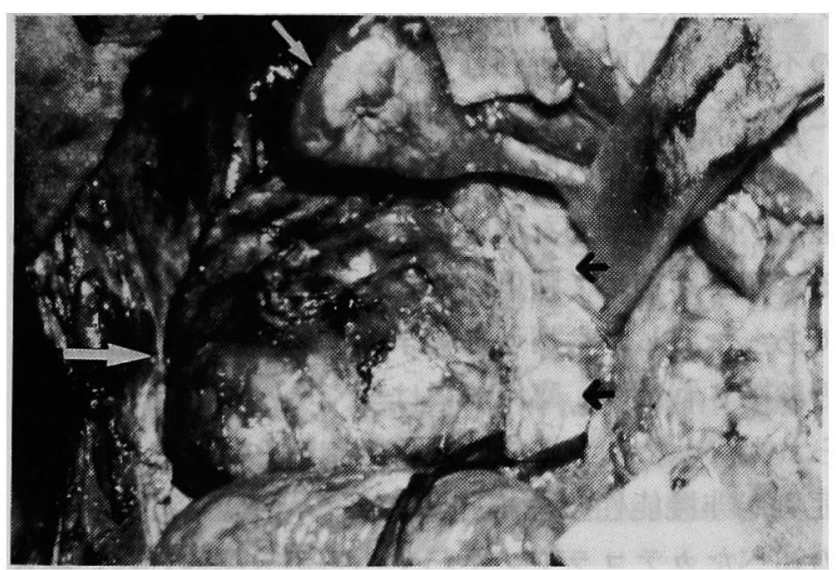

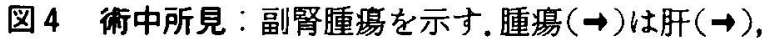
下大静脈（ケ）を後方から王排している。

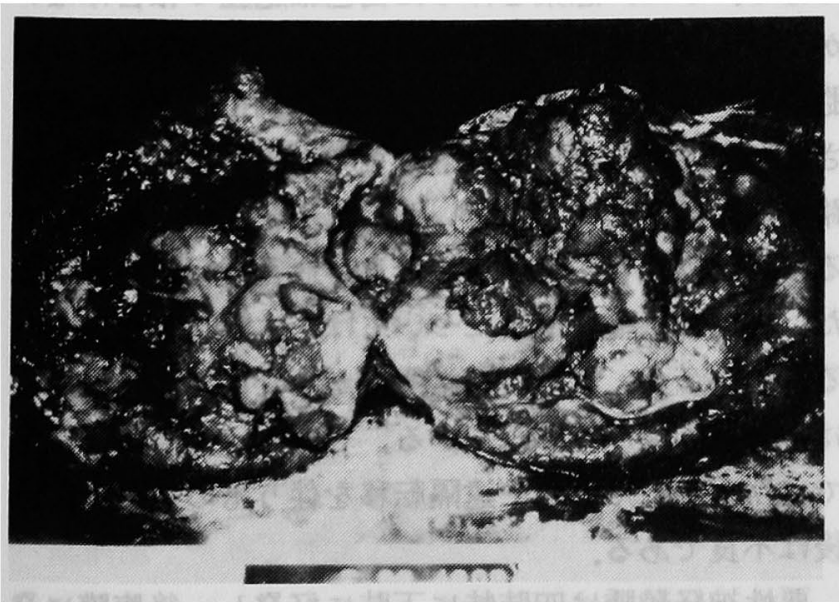

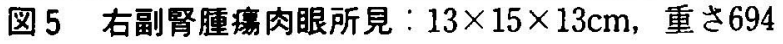
$\mathrm{g}$, 尰瘍表面は平滑. 割面では赤褐色の膿様液を入 れ，実質性部分は粗大結節状を呈していた。
むように発育するため，左胃動脈の合併切除を行い後 腹膜腫瘍も切除した。

切除標本の病理所見：図 5 のごとく，摘出した腫瘍 は $13 \times 15 \times 13 \mathrm{~cm}$, 重さ $698 \mathrm{~g}$, 赤褐色で表面は平滑で あったが，空気のぬけたボールのよらな外観を示して いた．割面では赤褐色の膿様液を入れ，壁は厚く結節 状隆起を示していた。大動脈腹側の腫瘍は図6のごと く $5 \times 5 \times 3 \mathrm{~cm}$, 黄色平滑でゴム様の硬さを示した。割面 は充実珄で中央にわずかに変性壊死巣がみられた。

病理組織学的所見としては副腎腫瘍の一部に正常組 織の遺残がみられたが，大部分は図 7 に示すごとく HE 染色では副腎髄質細胞に類似した腫瘍細胞が索状 あるいは充実性に増殖し，厚い線維性被膜内への浸潤 がみられた. Grimelius 染色は陽性であるため, 悪性褐 色細胞腫と診断された。

大動脈腹側の腫瘍は, 図 8 のごとくSchwann 細胞

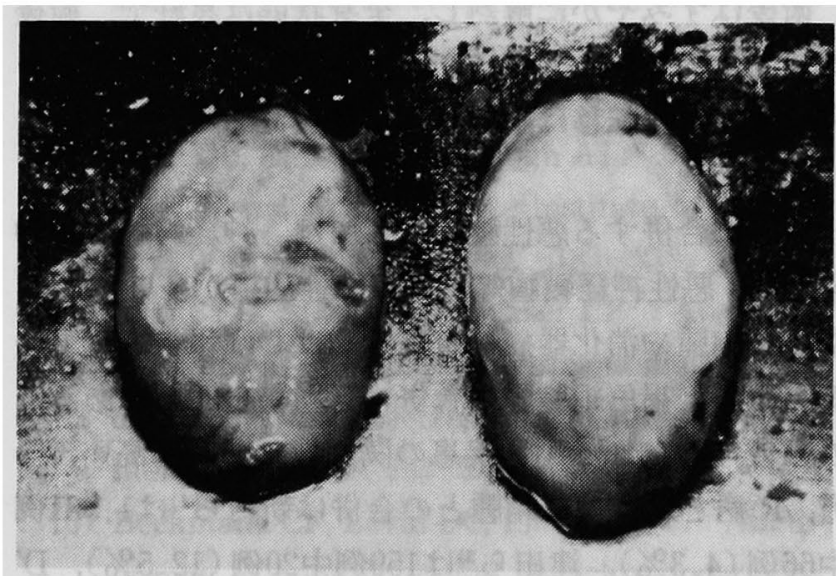

图 6 大動脈腹側腫嗉肉眼所見 : $5 \times 5 \times 3 \mathrm{~cm}$, 黄色, 表 面平滑。割面は黄色充実性であった。

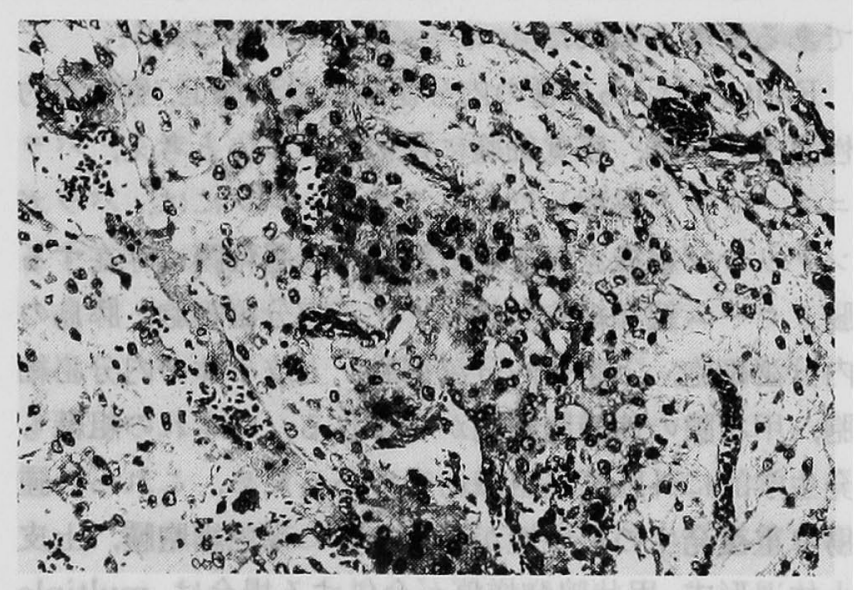

図 7 副腎腫瑒病理組織像：多形性で胞体が豊富な腫 湯細胞か，索状ないし充実性に増殖する（HE, $\times$ 400 ). 


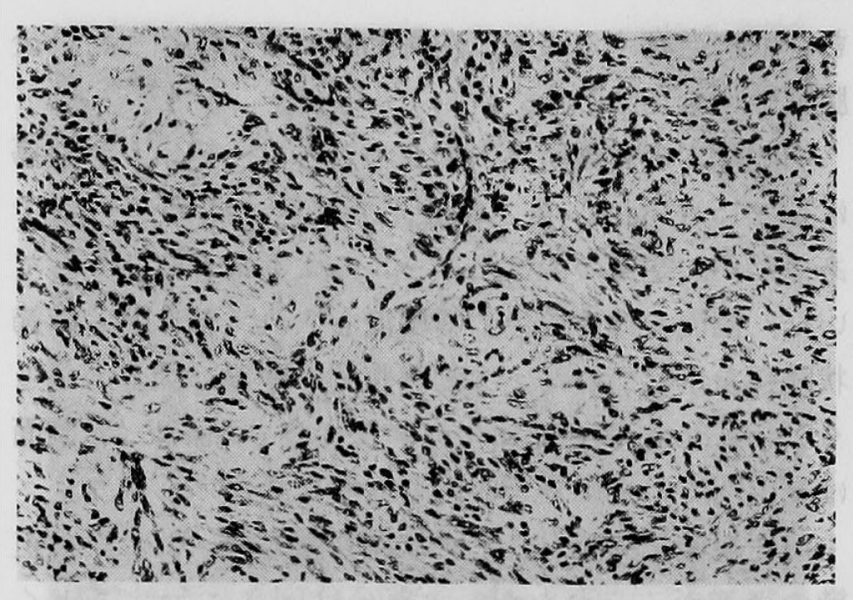

図 8 後腹膜腫病病理組織像: Schwann 細胞が索状 ないしらず巻状に増殖し，一部では cellularity が高 い $(\mathrm{HE}, \times 400)$

が索状に増殖し，一部に細胞密度の高い部分もみられ， 悪性を示唆する神経䩗腫と考えられた。

術後はすみやかに解熱し，全身状態は良好で，術後 25日で退院した。外来にて観察中であるが，1年 6 カ 月の現在再発転移は認められず健在である。

\section{考察}

$\mathrm{R}$ 病に合併する悪性腫瘍としては，神経肉腫，脳神

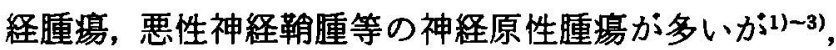
褐色細胞腫や消化器癌の合併もしばしば報告されてい る. $\mathrm{R}$ 病と褐色細胞腫の合併は $2 \%$ \% $20 \%$ あるると の報告もみられ(17)，両疾患の関連性は非常に高い。一 方， $\mathrm{R}$ 病と悪性神経鞴腫との合併は新村ら"1 1 (,531例 中66例 (4.3\%), 津田 $5^{3)}$ は159例中20例 (12.5\%), D Agostine ら ${ }^{9 /}$ は678例中21例（3.1\%）と報告している. しかしながら， R 病に褐色細胞腫と悪性神経鞘腫が合 併した例の報告は少なく6)，本症例はきわめて稀な例 であると考えられた。

Fujita ${ }^{10)}$ は, ある種の内分泌細胞は形態上, 生物学的 性質上, 神経, 感覚細胞に類似点が多いと考え, パラ ニューロンと総称した。 パラニューロンには，パラガ ングリオン組織を形成する細胞，胃腸粘膜に存在する 腸クロ一ム親和細胞を始めとする内分泌細胞，膵島の 内分泌細胞，下垂体内分泌細胞，上皮小体の内分泌細 胞，甲状腺の傍濾胞細胞が含まれる。いずれの組織 も 発生学的に外肧葉系組織由来であるため，これらの腫 湯は重複発生の可能性が高く，特に褐色細胞腫，上皮 小体過形成，甲状腺髄様癌が合併する場合は， multiple endocrine neoplasma type-2（Sipple 症候群）として 有名である.外肧葉組織由来の葴器に奇形を伴 $5 \mathrm{R}$ 病
には,パラニューロン由来の腫瘍が合併しやすい(6)7. これらのうちで，パラガングリオンから発生した腫瘍 はパラガングリオーマとよばれ，発生部位から副腎䯣 質由来の褐色細胞腫と副腎外ないし異所性の褐色細胞 腫（狭義のパラガングリオーマ）に分けられ，発生頻 度は前者が90\%，後者が10\%といわれている。

褐色細胞腫の多くは機能性腫湯であるために，過剩 分泌されたカテュラミンによる諸症状から腫瘍の存在 が疑われることが多いが，非機能性褐色細胞睡子少な からす゚報告されている. Sutton ら ${ }^{13)}$ は剖検により確診 の得られた褐色細胞腫54例を検討し，生前に診断可能 であったものは13例で, 残りの41例には特徽的な臨床 症状がなかったと報告している。臨床上無症状であっ ても血中, 尿中カテュラミンの上昇がみられ, 検査や 負荷試験，あるいは手術操作により血王上昇をきたす ものも多い.この点に関し, Page ら (4)は, (1)カテンラ ミンが全く分泌されない場合，(2)カテコラミンがわず かしか分泌されない場合, (3)尰瘍内においてアミン類 の不活化が高度に行われている場合, (4)各組織受容体 においてカテコラミンに対する高い耐性が蒦得されて いる場合の 4 つの原因をあげている，本症例は，副腎 腫瘍が感染性膿瘍を形成し大きな腫瘤として触知され るに至り，初めて腫瘍の存在に気づかれた特異な症例 であった.しかも病理組織学的には副腎の褐色細胞腫 と診断されたが，臨床的には全くホルモン活性が認め られないために非機能性褐色細胞腫と判断された。本 症例が非機能性褐色細胞腫であった原因は, Pageら の述べたカテコラミンがわずかしか分泌されない場合 と考えられたが,このような例は, Levitt ら

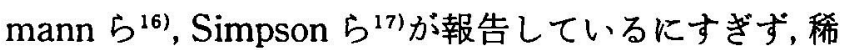
である。また，感染を伴った褐色細胞腫の報告はない が，巨大な褐色細胞腫では時に石灰化や壊死による桽 胞形成がみられる場合があり，本症例では鼠胞が形成 された上に感染が加ったすのと考えられる，感染の経 路や原因は明らかではないが，起炎菌が腸内細菌であ るので，消化管からの直接波及か血行性経路が疑われ た. 褐色細胞腫の治療については，本疾患は悪性であ ることが多く，有効な化学療法が少ないために，もっ ぱら外科切除が行われている。しかし，発見時にはす でに巨大化したものや遠隔転移を伴らすのが多く，予 後は不良である。

悪性神経䩗腫は四肢特に下肢に好発し，後腹膜に発 生することは20\%以下とされている5)，R 病に合併す る悪性神経䩗腫は神経線維腫の悪性化したものが多 
くまた，いずれの部位に発生する悪性神経䩗腫も巨 大な腫瘤を形成するまでは症状に乏しいため，小さな らちに発見され根治手術が施行された症例はまれであ $3^{9)}$. 本症例は他疾患の検索中に偶然発見された後腹 膜原発神経靽腫であり, 病理組織学的に悪性を示唂さ れていたが，根治的切除が可能であった。

したがって, 本症例の予後は, 後腹膜悪性神経靻腫 よりも非機能性悪性褐色細胞看により規定されるもの と予想される。

$$
\text { 結 語 }
$$

von Recklinghausen 病患者に発生した非機能性褐 色細胞腫と後腹膜悪性神経鞘腫の 1 切除例を報告し, 文献的考察を加えた。

\section{文献}

1) 新村真人：Recklinghausen 病, 自験 150 例および 本邦報告例について一内分泌，知能，脳波，悪性変 化一，皮庙臨 $16: 15-21,1974$

2）新村真人：Recklinghausen 病, 自験 150 例および 本邦報告例について一遺层，まとめ一，皮成臨 $16: 83-89,1974$

3）津田多加良, 村岡德保：Recklinghausen 病の本邦 159 例の統計的観察，臨外 $21: 1141-1144,1966$

4）尾崎行男，水沢清昭，牧野正人他：von Recklinghausen 病と悪性病変, 外科診療 25：119-122, 1983

5) Guccion JG, Enzinger FM : Malignant Schwannoma associated with von Recklinghausen's Neurofibromatosis. Virchows Archiv A $384: 43-57,1979$

6）佐藤辰男, 大石誠一，岩岡大輔他：褐色細胞腫, 日 臨 $41: 879-884,1983$

7) Quissel B, Mohammad A, Bauer JH, et al : Malignant pheochromocytoma in childhood; report of a case with familial neurofibrimatosis. Med Pediatr Oncol 7: 318-326, 1979
8）市川英幸，今井寿生，野口 徹他：悪性神経鞴腫 (malignant Schwannoma) の 3 例, 信州医誌 30 : 533-541, 1988

9) D'Agostino AN, Soule EH, Miller RH : Sarcomas of the peripheral nerves and somatic soft tissues associated with multiple neurofibromatosis. Cancer $16: 1015-1027,1963$

10) Fujita $T$ : The gastro-enteric endocrine cell and its paraneuronic nature. In Chromaffin Enterochromaffin, and Related cells (Coupland RE, Fujita T, eds), Elsevier Amsterdam, 1976, p191-208

11）笹野伸昭，若狭治毅，木村伯子他：バラニューロン の睡場，神経進歩 23:804-818, 1979

12）宮山東彦，大石誠一，佐藤辰男：副腎㖪質一WHO 分類を基にした各腫瘍の病理組織学的特徵一, 日 臨 $41: 1162-1168,1983$

13) Sutton MJ, Sheps SG, Lie JT: Prevalence of clinically unsuspected pheochromocytoma review of a 50-year autopsy series. Mayo Clin Proc 56 : 354-360, 1981

14) Page DL, DeLellis RA, Hough AJ : Tumors of the Adrenal Armed Forces Institute of Pathology, Washington, DC, 1986, p183-218

15) Levitt RG, Stanley RJ, Dehner LP : Angiography of a clinically nonfunctioning pheochromocytoma case report and review of the literature. JAMA 203 : 268-274, 1975

16) Beckmann CF, Levin DC, Phillips DA : Angiography of nonfunctioning pheochromocytomas of the adrenal gland. Radiology 124: 53-55, 1977

17) Simpson ET, Marszarek WW, Ramsaroop RR: Nonfunctioning pheochromocytoma. Urology 25 : 632-633, 1985 


\title{
A CASE OF VON RECKLINGHAUSEN'S DISEASE ASSOCIATED WITH NONFUNCTIONING PHEOCHROMOCYTOMA AND MALIGNANT SCHWANNOMA
}

\author{
Naoto HORIGOME, Hideo TSUNEMOTO, Kazuhiro HANAZAKI, Hideo MTYAMOTO, Eiichi SHIOHARA, \\ Shouji KAJIKAWA, Gengo KANEKO, Wataru ADACHI,
}

Futoshi IIDA and Keiko ISHI*

Second Department of Surgery and Department of Laboratory Medicine*, Shinshu University School of Medicine

A case of von Recklinghausen's disease associated with nonfunctioning pheochromocytoma and malignant schwannoma is reported. A 48-year-old female came to our hospital with the chief complaints of fever and abdominal mass. She had generally spread small skin tumors with café au lait spots. Her glandmother, mother and sister had been also pointed out to have von Recklinghausen's disease. Abdominal ultrasonography, computed tomography and angiography showed a huge adrenal tumor $13 \mathrm{~cm}$ in diameter and an egg-sized retroperitoneal tumor. The adrenal tumor appeared cystic and was suspected of abscess formation due to infection. As laboratory examinations revealed no endocrinological activity of the adrenal tumor, both tumors were resected without any preoperative treatments. The removed adrenal tumor measured $13 \times 15 \times 13 \mathrm{~cm}$ and weighed $649 \mathrm{~g}$. The center of the tumor was necrotic and contained brownish pus. The retroperitoneal tumor measured $5 \times 5 \times 3 \mathrm{~cm}$ and was yellow in color. The histological examination revealed malignant pheochromocytoma and malignant schwannoma, respectively. The patient is well at present, one and half year after operation. 